\title{
Perinatal lead and cadmium burden in a British urban population
}

\author{
I Z KOVAR, C D STREHLOW, J RICHMOND, AND M G THOMPSON \\ Department of Child Health, Westminster Medical School, London
}

SUMMARY Concentrations of the potential pollutants, lead and cadmium, were studied in the perinatal period in a British urban population. Blood lead and cadmium concentrations and iron status were measured in 28 mother and infant pairs at delivery and at five days postpartum in the mother; breast milk collected at five days postpartum under controlled conditions was analysed for lead and cadmium. Placental transfer of both metals was noted; concentrations of lead in breast milk (mean concentration $0.01 \mathrm{mmol} / \mathrm{l}(2 \mu \mathrm{g} / \mathrm{l})$ ) were less than in two brands of commercial prepacked formulas, and the concentration of cadmium in breast milk and prepacked formulas (mean $3.6 \mathrm{nmol} / \mathrm{l}(0.4 \mu \mathrm{g} / \mathrm{l})$ ) were similar. The risk of excess lead or cadmium intake from breast milk is small.

Children in modern society are at risk from the hazards of chemical environmental contaminants. ${ }^{1}$ Developing and growing nervous systems are at special risk; behavioural and learning disorders have been attributed to various chemical intoxicants, particularly lead ${ }^{2}$; the effects on developing nervous and other systems in man of lead exposure in utero are incompletely understood. ${ }^{3}$ Cadmium exposure in breeding rats may cause congenital abnormalities and fetal death ${ }^{4}$; in man a relation between cadmium, tobacco smoking, hypertension, and birthweight has been postulated. ${ }^{5}$ At the moment it is difficult to assess the association between exposure to levels of pollutant metals in the community and production of pathological disorders. Breast milk is often the only source of nutrition and may be an important source of continuing pollutant load in the perinatal period. ${ }^{6}$ We undertook a controlled study of lead and cadmium content of blood at delivery and of breast milk as part of a wider programme investigating potential pollutant burden to young infants in the United Kingdom.

\section{Material and method}

The study was conducted during a three month period (September-November 1980) at a single central London maternity hospital. Informed ethical consent was obtained and a detailed environmental history recorded for each mother. All pregnancies were medically uncomplicated and went to term (birthweight mean 3470 g (range $2920-4220 \mathrm{~g}$ )).
Samples of venous blood were collected from 28 mothers (mean age 29.2 years (range 24-37) years) at delivery and at the time of breast milk sampling five days postpartum. Blood from the umbilical cord was taken at delivery. Blood was collected into lithium heparin, edetic acid, and plain polystyrene tubes. Breast milk was collected from the right breast only during a morning feed $(10.00 \mathrm{am}-2.00$ pm). After five minutes of normal feeding $10 \mathrm{ml}$ of milk were directly expressed into polystyrene containers. All the containers of blood and milk samples were tested and found to be free of contamination by lead and cadmium. After collection the samples were kept at $4^{\circ} \mathrm{C}$ for not more than 12 hours and then stored at $-20^{\circ} \mathrm{C}$ until analysis.

Lead and cadmium concentrations were determined by automated atomic absorption spectrophotometry after electrothermal excitation; a graphite furnace (Instrumentation Laboratories: 555) and a carbon rod analyser (Varian: CRA-90) were used. Whole blood was analysed after precipitation of proteins with $3 \%$ nitric acid using the method of Stoeppler and Brandt. ${ }^{7}$ Breast milk and two prepacked commercial formulas were analysed by extraction of the lead and cadmium complexes of ammonium pyrolidinedithiocarbamate into methyl isobutyl ketone and direct injection into the graphite furnace. Quality assurance was maintained by using internal and external samples and by participating in an external quality control scheme for lead and cadmiun analysis. Certified commercial blood control samples (Behringwerke A G, Marburg F R G) 
were analysed on 13 separate occasions. For lead the certified concentration was mean (SD) $0.72(0.07)$ $\mu \mathrm{mol} / \mathrm{l}(15.0(1.5) \mu \mathrm{g} / 100 \mathrm{ml})$ whereas our method gave $0.73(0.06) \mu \mathrm{mol} / \mathrm{l}(15 \cdot 1(1.3) \mu \mathrm{g} / 100 \mathrm{ml})$, and for cadmium the certified concentration was 4.4 $(1 \cdot 8) \mathrm{nmol} / \mathrm{l}(0 \cdot 5(0 \cdot 2) \mu \mathrm{g} / \mathrm{l})$, whereas we found $4 \cdot 1$ $(1.2) \mathrm{nmol} / \mathrm{l}(0.46(0 \cdot 14) \mu \mathrm{g} / \mathrm{l})$.

Iron status was determined by analysis of the blood for haemoglobin, erythrocyte protoporphyrin (EPP), and serum ferritin concentrations. Haemoglobin and red cell indices were measured with a Coulter counter, EPP with an Environmental Science Associates haematofluorimeter calibrated against a standard extraction procedure ${ }^{8}$ and ferritin by radioimmunoassay with a commercially available kit (RIA (UK) Ltd).

The exposure of mothers and babies to airborne lead and cadmium was estimated by sampling particulate matter collected with membrane filters using equipment constructed to British Standard 1747; air samples were collected both outside the maternity hospital and inside the lying in wards.

\section{Results}

All but one of the mothers took iron supplements during pregnancy and 9 also took multivitamins. Six smoked more than 10 cigarettes a day throughout pregnancy and two until pregnancy was diagnosed. All 28 mothers lived in the London metropolitan area within two miles of a major highway and 18 within two miles of an industrial smoke stack. None of the occupations of the mothers or fathers put them at special risk of exposure to lead or cadmium.

Table 1 gives the results of analyses of blood lead and cadmium concentrations and iron status. There was no significant difference between EPP and serum ferritin in mothers' blood at delivery and at five days postpartum; mean haemoglobin was, however, significantly decreased at five days (paired $t$ test, two tailed) $(\mathrm{P}<0 \cdot 001)$. In contrast EPP and ferritin in cord blood were significantly increased in relation to mothers' blood at delivery $(\mathrm{P}<0 \cdot 001)$.

No significant difference for blood cadmium concentration between the three blood samples was found. When cadmium is compared on the basis of the mothers' smoking habits the mothers who smoked had a higher blood cadmium concentration only at five days $(\mathrm{P}<0 \cdot 05)$. The blood cadmium concentration in this group increased from a mean of $8.9 \mathrm{nmol} / \mathrm{l}(1.0 \mu \mathrm{g} / \mathrm{l})$ at delivery to $14 \mathrm{nmol} / \mathrm{l}(1.6$ $\mu \mathrm{g} / \mathrm{l})$ at five days postpartum; the non-smoking group did not show a corresponding change. In contrast to cadmium the lead concentration of the cord blood was significantly lower than that of mothers' blood at delivery $(\mathrm{P}<0 \cdot 05)$. There was no significant difference between mothers' blood at delivery and at five days postpartum.

Table 2 gives the results for lead and cadmium concentrations in breast milk. Nineteen samples were below the detection limit of the method for measuring lead concentration $(<0.01 \mu \mathrm{mol} / \mathrm{l}(<2$ $\mu \mathrm{g} / \mathrm{l})$ ); the maximum lead concentration was 0.04 $\mu \mathrm{mol} / \mathrm{l}(9 \mu \mathrm{g} / \mathrm{l})$. Ten samples had cadmium concentrations below the detection limit $(<2.7 \mathrm{nmol} / 1$ $(<0 \cdot 3 \mu \mathrm{g} / \mathrm{l}))$; the maximum cadmium concentration observed was $10.7 \mathrm{nmol} / \mathrm{l}(1.2 \mu \mathrm{g} / \mathrm{l})$. Only five samples had concentrations of both metals above the median concentrations of $<0.01 \mu \mathrm{mol} / \mathrm{l}(2 \mu \mathrm{g} / \mathrm{l})$ for lead and $2.7 \mathrm{nmol} / \mathrm{l}(0.3 \mu \mathrm{g} / \mathrm{l})$ for cadmium. In contrast to brest milk 6 samples of two brands of commercial prepacked milk formula were found to

Table 1 Analysis of blood from 28 mothers and umbilical cords for lead, cadmium, haemoglobin, erythrocyte protoporphyrin (EPP), and ferritin concentrations (mean (SD) and range) at delivery and at 5 days

\begin{tabular}{|c|c|c|c|}
\hline & \multicolumn{2}{|l|}{ Maternal blood } & \multirow[t]{2}{*}{ Cord blood } \\
\hline & At delivery & 5 days postpartum & \\
\hline Lead $(\mu \mathrm{mol} / \mathrm{l})$ & $\left\{\begin{array}{l}0.48(0.14)^{*} \\
0.24-0.87\end{array}\right.$ & $\begin{array}{l}0.49(0.16) \\
0.29-0.92\end{array}$ & $\begin{array}{l}0.42(0.09)^{*} \\
0.29-0.63\end{array}$ \\
\hline Cadmium (nmoll) & $\left\{\begin{array}{l}6 \cdot 13(5 \cdot 78) \\
0 \cdot 89-21.4\end{array}\right.$ & $\begin{array}{l}8 \cdot 1(4 \cdot 63) \\
1 \cdot 78-22 \cdot 2\end{array}$ & $\begin{array}{l}5 \cdot 25(4 \cdot 1) \\
0 \cdot 89-17 \cdot 8\end{array}$ \\
\hline Haemoglobin $(\mathrm{g} / \mathrm{dl})$ & $\left\{\begin{array}{l}13 \cdot 7(3 \cdot 0) \dagger \ddagger \\
11 \cdot 7-20 \cdot 3 \ddagger\end{array}\right.$ & $\begin{array}{l}11 \cdot 7(3.4) \dagger \neq \\
9 \cdot 9-16 \cdot 3\end{array}$ & $\begin{array}{l}16 \cdot 1(3 \cdot 0)^{\dagger} \\
12 \cdot 9-21 \cdot 9 \neq\end{array}$ \\
\hline $\operatorname{EPP}(\mu \mathrm{g} / \mathrm{dl})$ & $\left\{\begin{array}{l}8 \cdot 0(5 \cdot 9) \dagger \\
1-25\end{array}\right.$ & $\begin{array}{l}8 \cdot 7(9 \cdot 5) \\
1-40\end{array}$ & $\underset{3-71}{28 \cdot 4}(15 \cdot 2) \dagger$ \\
\hline Ferritin $(\mathrm{ng} / \mathrm{ml})$ & $\left\{\begin{array}{l}47 \cdot 2(44 \cdot 6)^{*} \\
9-164\end{array}\right.$ & $\begin{array}{l}53.9(63.4) \\
1-287\end{array}$ & $\begin{array}{l}100.9(58 \cdot 4)^{*} \\
54-264\end{array}$ \\
\hline
\end{tabular}

* $\mathrm{P}<0 \cdot 05 .+\mathrm{P}<0 \cdot 001$. Lead, cadmium, haemoglobin, and EPP all expressed in units of whole blood. Conversion: $S 1$ to traditional units-lead $1 \mu$ mol/l $\approx 20 \cdot 7$ $\mu \mathrm{g} / 100 \mathrm{ml}$; cadmium $1 \mathrm{nmol} / 1 \approx 0.11 \mu \mathrm{g} / \mathrm{l}$.

$\ddagger \mathbf{P}<0 \cdot 01$. 
Table 2 Lead and cadmium concentrations in breast milk collected five days postpartum

\begin{tabular}{|c|c|c|c|c|}
\hline & Mean & SD & Minimum & Maximum \\
\hline Lead $(\mathrm{nmol} / \mathrm{l}) \quad\left\{\begin{array}{l}(\mathrm{n}=28)^{*} \\
(\mathrm{n}=9)^{\dagger}\end{array}\right.$ & $\begin{array}{l}9 \cdot 7 \\
20\end{array}$ & $\begin{array}{l}10 \\
13\end{array}$ & $\begin{array}{r}<9.7 \\
9.7\end{array}$ & $\begin{array}{l}43 \\
43\end{array}$ \\
\hline Cadmium (nmol/l) $\left\{\begin{array}{l}(\mathrm{n}=28)^{*} \\
(\mathrm{n}=18) \dagger\end{array}\right.$ & $\begin{array}{l}3 \cdot 6 \\
4 \cdot 7\end{array}$ & $\begin{array}{l}2 \cdot 5 \\
2 \cdot 4\end{array}$ & $\begin{array}{r}<2 \cdot 7 \\
2 \cdot 7\end{array}$ & $\begin{array}{l}10 \cdot 7 \\
10 \cdot 7\end{array}$ \\
\hline
\end{tabular}

* Mean and standard deviation for all samples with undetectable con centrations taken as one half of the detection limit-that is, $4.8 \mathrm{nmol}$ lead/l and $1.3 \mathrm{nmol}$ cadmium/l.

+ Means and standard deviations excluding samples below the detection limits of $4.8 \mathrm{nmol}$ lead/l and $1.3 \mathrm{nmol}$ cadmium/l.

Conversion: SI to traditional units - lead $1 \mathrm{nmol} / \mathrm{l} \approx 0.2 \mu \mathrm{g} / \mathrm{l}$; cadmium $1 \mathrm{nmoV} /$ $=0.11 \mu \mathrm{g} / \mathrm{l}$.

contain mean concentrations of $0.02 \mu \mathrm{mol} / \mathrm{l}(4 \mu \mathrm{g} / \mathrm{l})$ lead and $<2.7 \mathrm{nmol} / \mathrm{l}(<0.3 \mu \mathrm{g} / \mathrm{l})$ cadmium. The airborne concentration inside the hospital wards averaged $0.003 \mu \mathrm{mol}(0.7 \mu \mathrm{g}) \mathrm{lead} / \mathrm{m}^{3}$ and $0.02 \mathrm{nmol}$ $(1.7 \mathrm{ng}) \mathrm{cadmium} / \mathrm{m}^{3}$ for the duration of the study, and those outisde the hospital averaged 0.004 $\mu \mathrm{mol}(0.8 \mu \mathrm{g}) \mathrm{lead} / \mathrm{m}^{3}$ and $0.01 \mathrm{nmol} / \mathrm{l}(1.3 \mathrm{ng})$ cadmium $/ \mathrm{m}^{3}$.

\section{Discussion}

Lead and cadmium are known pollutants that may cause disease in man. Concern has in particular been expressed about the potential neuropsychiatric effects of lead at subtoxic concentrations in young children, ${ }^{2}$ but little is known about the cumulative effects of either metal on the developing fetus and newborn infant.

Expectant mothers are exposed to pollutants through ingestion of food and water and through exposure to airborne dusts from industrial and vehicle emissions. ${ }^{3}$ Airborne sources of lead have not been considered a major hazard, ${ }^{9}$ but this has been disputed. The airborne concentrations of lead and cadmium in the hospital wards studied were similar to urban values we have measured elsewhere in the UK (Department of Child Health, Westminster Medical School, unpublished data). The body burden of newborn infants comes from transplacental transfer, the airborne environment, and, in early life, milk. This study shows that lead and cadmium cross the placenta and are present in breast milk. The data are in broad agreement with other published work despite differences in methodology and control of specimen collection. ${ }^{10} 11$

Although lead in cord blood was significantly lower than in mothers' blood at delivery, the difference was small and indicates that the placenta offers no significant barrier to the transfer of lead. This observation and the lack of difference between mothers' blood at delivery and five days postpartum suggests that blood lead concentrations are not subject to haemodilution during pregnancy and are available for transfer to breast milk. The lead concentrations found in breast milk were lower than in the two commercial prepacked formulas; in areas with increased concentrations of lead in water an additional burden may be provided with reconstituted formulas. ${ }^{12}$

An average $3 \mathrm{~kg}$ baby requires $150 \mathrm{ml} / \mathrm{kg}$ bodyweight/day of milk; the potential burden from this source would be $10 \mathrm{nmol}(1.8 \mu \mathrm{g}) \mathrm{lead} /$ day from prepacked formula but less than $4 \mathrm{nmol}(0 \cdot 9 \mu \mathrm{g}) /$ day from breast milk. Corresponding loads for cadmium would be $1.2 \mathrm{nmol}(0 \cdot 14 \mu \mathrm{g}) / \mathrm{day}$ from both breast milk and formulas. The calculated daily intake of lead is well below suggested permissible limits for adults and older children. ${ }^{13}$ Newborn infants may, however, retain more lead than adults do. ${ }^{14}$

The increased EPP concentrations seen in the cord blood could conceivably be associated with lead exposure or iron dificiency. ${ }^{15}$ All but one of the mothers participating in the study were taking iron supplements and none were deficient. The parallel increases in haemoglobin and serum ferritin concentrations in cord blood are thought to be due to a high red cell mass in the fetus. ${ }^{16}$ An increased EPP concentration due to lead exposure in children develops only above blood lead concentrations of 1 $\mu \mathrm{mol} / \mathrm{l}(20 \mu \mathrm{g} / 100 \mathrm{ml}) \cdot{ }^{17}$ As our maternal and cord blood concentrations averaged less than $0.5 \mu \mathrm{mol} / \mathrm{l}$ $(10 \mu \mathrm{g} / 100 \mathrm{ml})$ the observed cord blood EPP concentration is unlikely to have been due to lead toxicity in utero. In the neonatal period one third of the total EPP concentration is in the free rather than the zinc chelated form characteristic of older children and adults. The free form is not detected after 7-10 days and has been attributed to immature erythrocytes in cord blood. ${ }^{18}$ Our analytic method does not distinguish between these two forms, and therefore the zinc protoporphyrin content of cord blood is close to that in the mother.

Increased concentrations of cadmium in the placenta have been reported, suggesting that the placenta acts as a barrier to transfer ${ }^{10}$ Our data fail to confirm this because there was no significant difference between concentration in mothers' blood and cord blood at delivery. The increase in blood cadmium concentrations observed in mothers between delivery and five days postpartum was significant only for the smokers. ${ }^{19}$ This change in concentration is unlikely to reflect a major increase in cigarette consumption; the findings most likely indicate a re-equilibration of mothers' blood cadmium concentration with cadmium stores after birth. The blood examined five days postpartum 
may give a truer picture of the mothers' previous cadmium exposure and it may be argued that the placenta acts as a 'sink' for cadmium without inhibiting transfer.

Our data suggest that the risk of excess lead and cadmium in breast milk is low. When other foods are substituted the risk increases. ${ }^{20}$ The potential effects, even from low concentrations, cannot, however, be discounted.

We thank nursing Sisters M Bond, D Fish, and K-K Forrest and the nurses of the labour and postnatal wards of Queen Charlotte's Maternity Hospital, London, for their help, the Special Trustees of Westminster Hospital for financial support, and Professor D Barltrop for advice.

\section{References}

1 Anonymous. Environmental hazards and the paediatrician (Editorial). J Pediatr 1981;99:400-1.

2 Moore MR. Exposure to lead in childhood. The persisting effects. Nature 1980;283:334-5.

${ }^{3}$ Longo LD. Environmental pollution and pregnancy: risk and uncertainties for the fetus and infant. Am J Obstet Gynecol 1980;137:162-73.

4 Ahokas RA, Ditls PV. Cadmium uptake by the rat embryo as a function of gestational age. Am J Obstet Gynecol 1979;135:21922.

5 Huel G, Boudene C, Ibrahim M. Cadmium and lead content of maternal and newborn hair: relationship to parity, birthweight and hypertension. Arch Environ Health 1981;36:221-7.

${ }^{6}$ Giacoia GP, Catz CS. Drugs and pollutants in breast milk. Clin Perinatol 1979;6:181-95.

7 Stoeppler M, Brandt K. Contributions to automated trace analysis. Part 5. Determination of cadmium in whole blood and urine by electrothermal atomic-absorption spectrophotometry. Zeitschrift für Analytsche Chemie 1980;300:372-80.
${ }^{8}$ Chisholm J. Brown DH. Micro-scale photofluorometric determination of free erythrocyte protoporphyrin (protoporphyrin IX). Clin Chem 1975;21:1669-82.

9 DHSS. Lead and health. Report of a DHSS Working Party on lead in the environment. London: HMSO, 1980.

${ }^{10}$ Lauwerys R, Buchet JP. Raels H, Hubermont G. Placental transfer of lead, mercury, cadmium and carbon monoxide in women. Environ Res 1978;15:278-83.

${ }^{11}$ Larsson B, Slorack SA, Hagman V, Hofvander Y. WHO collaborative breast feeding study. Acta Paediatr Scand 1981;70:281-4.

12 Department of the Environment. Glasgow duplicate diet study 1979/80. Pollution report II. London: Department of the Environment. 1981.

13 Mahaffey KR. Relation between quantities of lead ingested and health effects of lead in humans. Pediatrics 1977:59:448-55.

14 Momcilovic M, Kostial K. Kinetics of lead retention and distribution in suckling and adult rats. Environ Res 1974:8: 214-40.

15 Yip R, Norris TN, Anderson AS. Iron status of children with elevated blood lead concentrations. J Pediatr 1981;99:922-5.

16 Willoughby MLN. Paediatric haematology. Edinburgh: Churchill Livingstone, 1977:1-12.

17 Strehlow CD, Barltrop D. Inter-relationships of blood lead, FEP, and iron status, Montreal: 2nd International conference of clinical chemistry and chemical toxicology of metals, July 1983.

18 Chisholm JJ Jr, Brown DH. Micromethod for zinc protoporphyrin in erythrocytes: including new data on the absorptivity of zinc protoporphyrin and new observations in nconates and sickle celı disease. Biochem Med 1979;22:214-37.

19 Lewis GP. Coughlin LL, Jusko WJ, Hartz S. Contribution of cigarette smoking to cadmium accumulation in man. Lancet $1972 ; \mathbf{i}: 291-2$.

${ }^{20}$ Mitchell DG. Lead contamination in milks fed to infants: 1972-1973. Paint is not the only problem. Pediatrics 1974;53:142-3.

Correspondence to $\operatorname{Dr}$ I Z Kovar, Department of Child Health, Westminster Children's Hospital, Vincent Square, London SW1P 2NS.

Received 26 October 1983 